\title{
Zorgplichten aan het werk
}

\author{
W. Timmer
}

'Principles based regulation is not possible for people who have no principles.' ${ }^{1}$

\section{Inleiding}

Wetgevingsjuristen zien zich regelmatig geconfronteerd met de vraag of het wenselijk en verstandig is een voorschrift vorm te geven als zorgplichtbepaling. Daarbij staat voorop de vraag of een dergelijke juridische figuur in de praktijk ook zal werken. Knelpunten in de naleving en de handhaving van een zorgplicht spelen hierin een grote rol. Deze bijdrage beoogt een antwoord te geven op de vraag: wat zijn de belangrijkste omstandigheden en voorwaarden waarmee de wetgever, als hij gebruik wil maken van zorgplichtbepalingen, rekening moet houden om de behoorlijke naleving en handhaving ervan te borgen? Dit artikel verkent tegelijkertijd de daaraan voorafgaande vraag: hoe komt het dat in de praktijk van zorgplichten niet steeds volledig wordt bereikt wat de wetgever voor ogen stond? Het antwoord op deze vragen is ontleend aan literatuurstudie en aan eigen onderzoek. $^{2}$

Deze bijdrage begint met een korte schets van doelregelgeving en zorgplichten, en zet uiteen wat daarvan de state of the art is in de wetgevingspraktijk en de literatuur (par. 2 en 3). Vervolgens wordt belicht wat de belangrijkste theoretische noties zijn waaraan een goede zorgplichtbepaling dient te voldoen (par. 4-7). Daarna wil ik aan de hand van een praktijkvoorbeeld - een casusonderzoek inzake het laden en lossen van gevaarlijke stoffen - toelichten hoe dergelijke noties in de praktijk gestalte krijgen (par. 8). De bijdrage sluit af met aanbevelingen, die voortvloeien uit het casusonderzoek tegen het licht van die theoretische noties (par. 9). De aanbevelingen bevatten de belangrijkste elementen van een afwegingskader voor de wetgever.

\section{Wat is een zorgplicht?}

Een zorgplicht is een vorm van doelregelgeving die de nadruk legt op de te bereiken uitkomst (het doel). Het geeft de geadresseerde de vrijheid om op zijn eigen

1 J. Black, The Rise, Fall and Fate of Principles Based Regulation, Londen: London School of Economics and Political Science, Law Department 2010, p. 23.

2 W. Timmer, Het doel wel gesteld. Een praktijkonderzoek naar de toepassing van doelregelgeving (diss. Rotterdam), Den Haag: Boom Juridische uitgevers 2011. Voor een beknopt overzicht van het onderzoek zie W. Timmer, 'Doelregelgeving: op zoek naar een werkend concept', Tijdschrift voor Wetgeving 2012, nr. 4, p. 258-271. 
wijze die uitkomst te bereiken. ${ }^{3}$ Een voorbeeld is artikel 3 lid 1 onderdeel a van de Arbeidsomstandighedenwet (Arbowet):

'Tenzij dit redelijkerwijs niet kan worden gevergd organiseert de werkgever de arbeid zodanig dat daarvan geen nadelige invloed uitgaat op de veiligheid en de gezondheid van werknemers.'

Niet alle doelvoorschriften hebben dezelfde eigenschappen, dezelfde voordelen of dezelfde nadelen. Een belangrijk onderscheid is dat tussen een concreet en een meer abstract doelvoorschrift. ${ }^{4}$ De eerste categorie bevat een grenswaarde, bijvoorbeeld een meetbare maximale uitstoot van stoffen. Daarvan is eenduidig vast te stellen of eraan is voldaan: dit is een kwantitatieve doelstelling. De tweede categorie betreft de kwalitatieve doelstelling en omvat de zorgplichten, ${ }^{5}$ met de te bereiken uitkomst neergelegd in een open norm. ${ }^{6}$ Het aangehaalde artikel 3 Arbowet is hiervan een voorbeeld.

Een doelvoorschrift of een zorgplicht heeft de volgende materiële kenmerken:

1. In het voorschrift ligt de nadruk op de te bereiken uitkomst (het doel).

2. De normadressaat heeft de vrijheid om op zijn eigen wijze de uitkomst van het voorschrift te bereiken; bij hem ligt het initiatief voor de aanpak om tot de uitkomst te komen, en niet bij de regelsteller.

3. Er worden geen - of slechts in beperkte mate - specifieke handelingen voorgeschreven.

3 Doelregelgeving staat in deze zin tegenover de (meer traditionele) middelregelgeving, die concrete handelingsvoorschriften bevat en niets regelt over het te bereiken doel. Synoniemen van middelregelgeving zijn: gedragsregelgeving, gedragregulerende of maatregelgerichte bepalingen, command and control-normen, procesregulering en handelingsnormen.

4 Kamerstukken II 2005/06, 30 552, nr. 3 (MvT Wijziging van de Arbeidsomstandighedenwet 1998), p. 8.

5 W.J. Witteveen, 'Alternatieve regulering: de vele gezichten van de wetgever', in: Alternatieve regelgeving, preadviezen voor de Nederlandse Juristen-Vereniging, Deventer: Kluwer 2007, p. 23 ziet zorgplicht en doelregelgeving als verwante, naast elkaar staande begrippen; mijn uitgangspunt is dat zorgplichten een species zijn van het genus doelregelgeving of doelvoorschriften.

6 S.J.A. ter Borg, N.J.H. Huls, N. Saanen, W.S.R. Stoter \& H.D. Stout, Doelgericht wetgeven. Doelvoorschriften in literatuur en praktijk, Den Haag: Ministerie van Verkeer en Waterstaat 2009, p. 12 bevat een uitgebreidere inventarisatie van typen doelregelgeving. Voor een checklist zie S. Stoter \& H. Stout, 'Doelregelgeving met beleid', Bestuurswetenschappen 2010, nr. 2, p. 58-70. 


\section{Zorgplichten in de literatuur}

Aan de toepassing door de wetgever van doelregelgeving en zorgplichten liggen vooronderstelde voordelen of motieven ten grondslag. In de literatuur worden diverse motieven genoemd. ${ }^{7}$ Drie hoofdstromen zijn daarin te onderscheiden:

1. Regelingen hoeven niet steeds te worden aangepast aan technische en andere ontwikkelingen, hetgeen innovatie bevordert.

2. De verantwoordelijkheid voor proces en resultaat wordt verplaatst van de regelgever naar de normadressaat. Diens professionaliteit en kennis van de concrete omstandigheden komen daardoor tot hun recht. De normadressaat kan zodoende aansluiten bij zijn eigen bedrijfsprocessen, wat een economisch voordeel betekent.

3. Het is lastig voor de regelgever om alle denkbare situaties op voorhand te bestrijken met regels. Naarmate zorgplichten abstracter zijn geformuleerd, lijden zij minder dan middelregelgeving aan over- en underinclusiveness, hetgeen de kansen op maatwerk en flexibiliteit vergroot.

De zorgplichtbepaling heeft ook keerzijden. Zo kan deze, door het ontbreken van concrete handelingsvoorschriften, leiden tot een riskante reductie van kosten. Een voorbeeld is de fatale ontsporing van de sneltrein te Eschede (Duitsland) in 1998; daarvan was een te goedkoop uitgevoerd wiel de oorzaak. ${ }^{8}$ Verder kan doelregelgeving, wegens de noodzaak tot nadere interpretatie ervan, leiden tot regelproliferatie. ${ }^{9}$ Een andere beperking van deze vorm van regelgeving is dat zij soms een dosis (politieke) retoriek meebrengt, verpakt in termen als wederkerigheid, vertrouwen of verantwoordelijkheid. ${ }^{10}$

Bovengenoemde aspecten (motieven en nadelen) vormen ingrediënten voor de in deze bijdrage te schetsen aanbevelingen. Deze aspecten vormen een leidraad, zowel voor de wetgever om vast te stellen of een zorgplichtbepaling in het specifieke geval een nuttig en bruikbaar concept is, als voor de geadresseerde, opdat hij weet wat er van hem wordt verwacht. De aanbevelingen zijn tot stand gekomen

7 Zie bijv. J. Black, Forms and Paradoxes of Principles Based Regulation, Londen: London School of Economics and Political Science, Law Department 2008, p. 3; H.C. Blakstad, Revising Rules and Reviving Knowledge Adapting Hierarchical and Risk-Based Approaches to Safety Rule Modifications in the Norwegian Railway System (diss. Trondheim), 2006, p. 6; 'Bruikbare rechtsorde', Kamerstukken II 2003/04, 29 278, nr. 9, p. 19-20; R. van Gestel, Zelfregulering, milieuzorg en bedrijven (diss. Tilburg), Den Haag: Boom Juridische uitgevers 2000, p. 185; A.R. Hale, 'Safety Rules O.K.?' Journal of Occupational Accidents 1990, nr. 12, p. 38; Onderwijsraad, Doortastend onderwijstoezicht (advies uitgebracht aan de minister van Onderwijs, Cultuur en Wetenschap), Den Haag 2006, p. 18; P.C. Westerman, 'Normering via doelstelling: zorgplichten', in: P.C. Westerman \& A.R. Mackor (red.), Vormen van (de?)regulering, Den Haag: Boom Juridische uitgevers 2008, p. 53; Projectgroep zorgplichten primair onderwijs, Zorgplichtbepalingen in het primair onderwijs, bijlage bij Kamerstukken II 2005/06, 27 728, nr. 85, p. 7, 11, 13 en 16.

8 G. Becker, 'Towards Goal-Directed Regulation in a Competitive World: Do We Underestimate the Risk of Changes in the Regulatory System?', in: B. Kirwan, A. Hale \& A. Hopkins (red.), Changing Regulation: Controlling Risks in Society, Oxford: Pergamon 2002, p. 128 en 133.

9 In het Engels: regulatory creep; zie Better Regulation Task Force, Avoiding Regulatory Creep, Londen: Whitehall 2004.

10 Black 2008, p. 10 en 17; 2010, p. 12. De Engelstalige literatuur spreekt van principles. 
door het theoretische kader te beproeven in een tweetal casestudies (casusonderzoeken). Een daarvan wordt hierna beschreven in paragraaf 8.

\section{Normadressaat als invalshoek}

Het voornaamste onderscheidende aspect van zorgplichtbepalingen ten opzichte van de meer traditionele middelregelgeving is de vrijheid voor de geadresseerde om naar eigen inzicht middelen in te zetten om het gestelde doel te bereiken. De normadressaat is in deze bijdrage dan ook de centrale actor. ${ }^{11}$ Bij zorgplichten spelen een hoofdrol de professionaliteit en de deskundigheid van de normadressaat, de mate waarin hij de regelgeving onderschrijft, zijn belangen en verantwoordelijkheden, zijn interesse voor de normatieve lading van het doelvoorschrift, zijn kernactiviteiten, en het vertrouwen van de overheid op zijn vernuft. Een juiste keuze van de normadressaat door de wetgever is daarom in het bijzonder van belang. Het doet er namelijk toe wie normadressaat is van de zorgplichtbepaling, omdat de wetgever moet kunnen vaststellen welke en wiens specifieke professionaliteit kan bijdragen aan het bereiken van het doel van de zorgplicht. Doel en geadresseerde moeten daarom, meer nog dan bij een middelvoorschrift, bij elkaar passen.

\section{Vrijwillige naleving}

Het begrip naleving heeft in het algemeen de betekenis van: het zich feitelijk gedragen volgens bepaalde regels, waaronder begrepen het zich onthouden van gedrag dat door die regels wordt verboden. ${ }^{12}$ Anders dan bij middelregelgeving staat niet op voorhand vast op welke wijze de zorgplicht moet worden nageleefd, aangezien er geen eenduidige interpretatie van de norm is. Naleving betekent hier dat de geadresseerden het door de regelgever beoogde doel weten te bereiken met door henzelf gekozen middelen. Aan hen worden daarom verdergaande eisen gesteld dan aan geadresseerden van middelregelgeving.

Naleving van voorschriften kan plaatsvinden op vrijwillige basis (uit eigen beweging) of onder de druk van handhaving. Naarmate de vrijwillige naleving groter is, behoeft minder handhaving plaats te vinden. Om een bijzondere reden verdient

11 Zie over de invalshoek van de geadresseerde in het juridisch onderzoek in plaats van de gangbare juridische autoriteiten als de wetgever of de rechter: H.S. Taekema, Het probleem van pragmatisme. Een vertrekpunt voor rechtstheorie en rechtsmethodologie (oratie Rotterdam), Den Haag: Boom Juridische uitgevers 2010, p. 20-21.

12 J. van Erp, 'Motieven voor naleving van regelgeving: recente gedragswetenschappelijke inzichten', in: T. Barkhuysen, W. den Ouden \& J.E.M. Polak (red.), Recht realiseren. Bijdragen rond het thema adequate naleving van rechtsregels, Deventer: Kluwer 2005, p. 16. 
vrijwillige naleving ${ }^{13}$ bij doelregelgeving de voorkeur boven gestuurde of afgedwongen naleving. Immers, alleen bij bereidheid tot vrijwillige naleving maken gereguleerden optimaal gebruik van hun eigen deskundigheid en professionaliteit om de uitkomst van de norm zelf te definiëren en de daarbij behorende middelen te kiezen. Deskundigheid en professionaliteit bij de geadresseerden zijn dan ook belangrijke feitelijke voorwaarden voor een wijze van naleven zoals de wetgever die beoogt. Bij afgedwongen naleving daarentegen is het een buitenstaander, de handhaver, die de keuzen maakt of die het bedrijf dwingt die keuzen te maken. Dat is als duwen tegen een touw. Dan zijn de prikkels van de eigen deskundigheid geringer en zal de justitiabele niet ten volle zijn handelingsvrijheid, inherent aan de zorgplicht, kunnen of willen aanwenden. Het doelbereik van de zorgplichtbepaling zal bijgevolg kleiner zijn dan bij meer vrijwillige naleving. Wezenlijk voor de vrijwillige naleving is dat het doelvoorschrift bij de doelgroep bereidheid creëert om haar veronderstelde professionaliteit en deskundigheid optimaal in te zetten. Naarmate het voorschrift beter bij de geadresseerden past, kan een succesvollere norm worden verondersteld in termen van naleefbaarheid. Daarom moet het doelvoorschrift aansluiten bij in ieder geval twee elementen: het eigen belang van de geadresseerde en diens professionele deskundigheid. ${ }^{14}$

\section{Naleving en communicatieve wetgeving}

Een belangrijke modaliteit van de naleving is het communicatieve gehalte van de wetgeving. De communicatieve theorie beoogt de wetgever erop te attenderen dat hem bij het opstellen van een wet de doelgroep zo veel mogelijk voor ogen moet staan. Ook streeft deze theorie naar het vervolgen van de dialoog na de inwerkingtreding van een wet; de discussie wordt voortgezet in een discours, bijvoorbeeld door rechters, bestuursorganen of belangenorganisaties. Kenmerk van communicatieve wetgeving is de aspiratieve norm, die een bepaalde gewenste richting aanduidt. Aspiratieve normen zijn rechtsnormen waarvan de betekenis (nog) niet geheel is uitgekristalliseerd, maar die fundamentele streefdoelen of idealen vertegenwoordigen in de samenleving. ${ }^{15}$ Vertaald naar doelregelgeving: de geadresseerde moet 'iets hebben' met de norm en met haar doelstelling. Als een norm dusdanig is uitgekristalliseerd dat zij goed functioneert, is het daaraan vooraf-

13 Ook wordt wel gesproken van 'verinnerlijking'; M.L.M. Hertogh, 'Van naleving naar beleving van regels. Bouwwereld en bouwfraude vanuit een rechtssociologisch perspectief', in: T. Barkhuysen, W. den Ouden \& J.E.M. Polak (red.), Recht realiseren. Bijdragen rond het thema adequate naleving van rechtsregels, Deventer: Kluwer 2005, p. 67; A.F.M. Brenninkmeijer, 'Nakoming van rechtsnormen: tussen orde en chaos', in: T. Barkhuysen, W. den Ouden \& J.E.M. Polak (red.), Recht realiseren. Bijdragen rond het thema adequate naleving van rechtsregels, Deventer: Kluwer 2005, p. 232.

14 P.C. Westerman, 'Outputsturing in de rechtsstaat', RMThemis 2006, nr. 6, p. 237-241 ziet de parallelliteit van belangen tussen overheid en gereguleerde als een goede basis voor handelingsvrijheid voor de normadressaat.

15 Een voorbeeld is het discriminatieverbod in art. 1 van de Grondwet (Gw); B. van Klink, 'Symboolwerking van gelijke-behandelingswetgeving', Nemesis 1999, nr. 1, p. 7. 
gaande discours nodig geweest om nadere invulling te geven aan de open norm. ${ }^{16}$ In de praktijk zal een dergelijk discours vaak gevoerd worden tussen de toezichthouders enerzijds en de ondertoezichtstaanden anderzijds. ${ }^{17}$

In de theorie van de communicatieve wetgeving is ten slotte van belang dat er een interpretatiegemeenschap is, een samenhangende doelgroep die met de aspiratieve norm overweg kan en die haar handen en voeten geeft. ${ }^{18}$ Interpretatiegemeenschap is als begrip breder dan de enkele groep normadressaten: ook handhavers kunnen er deel van uitmaken. Een interpretatiegemeenschap is alleen functioneel als zij de doelstellingen van de norm onderschrijft. Ook moet binnen de gemeenschap overeenstemming bestaan over de vraag hoe met verscheidenheid aan inzichten binnen de groep wordt omgegaan.

\section{Handhaving als achilleshiel}

Handhaving is elke vorm van feitelijk overheidsoptreden dat middellijk of onmiddellijk is gericht op het voorkomen van regelovertreding of op het ongedaan maken van een rechtens onjuiste situatie. ${ }^{19}$ Handhaven is het doen naleven van rechtsregels. ${ }^{20}$

Er zijn verschillende vormen van handhaving, bijvoorbeeld de strafrechtelijke handhaving, zoals opsporing en vervolging, en het toezicht, een vorm van de bestuursrechtelijke (of bestuurlijke) handhaving. Voor zorgplichtbepalingen als vorm van doelregelgeving is het van belang dat het sanctieregime aansluit bij de bijzondere aard van deze vorm van reguleren. Het sanctieregime moet onderdeel vormen van de responsieve toezichtstrategie, waaraan een vorm van discours ten grondslag ligt. Bestuurlijke handhaving lijkt daarbij beter te passen dan strafrechtelijke. In een hard punitief klimaat zal doelregelgeving namelijk niet overleven. ${ }^{21}$ Belangrijk is dat vertrouwen bestaat in de verantwoordelijkheid van de normadressaat bij zowel de regelgever als de handhaver. ${ }^{22}$

16 A. Azimi, Open norm als maatwerk? De communicatieve benadering toegepast op de Arbeidsomstandighedenwet 1998 (diss. Tilburg), Nijmegen: Wolf Legal Publishers 2007, p. 4 e.v.

17 Black 2008, p. 9 en 17; 2010, p. 6. F. Mertens, 'Toezicht en dynamiek', Tijdschrift voor toegepaste Arbowetenschap 2010, nr. 1, p. 30-37 stelt zelfs dat een dispuut met de toezichthouder een indicatie is voor de vitaliteit van de toezichtrelatie. Waar geen dispuut is, moet de toezichthouder bij zichzelf te rade gaan of het toezicht wel voldoende betekenisvol is.

18 B. van Klink, De wet als symbool: over wettelijke communicatie en de Wet gelijke behandeling van mannen en vrouwen bij de arbeid (diss. Tilburg), Deventer: W.E.J. Tjeenk Willink 1998, p. 94 e.v.

19 C.D. van der Vijver \& R.M. Kouwenhoven, Handhaven: eerst kiezen, dan doen. Bestuurlijke mogelijkheden en beperkingen. Deelrapport II, Den Haag: Ministerie van Justitie 2004, p. 22; F.C.M.A. Michiels, Bestuurlijke handhaving in ontwikkeling, preadvies in Handhaving van het bestuursrecht, VAR-reeks 114, Alphen aan den Rijn: Samsom H.D. Tjeenk Willink 1995, p. 12.

20 F.C.M.A. Michiels, 'Handhavingsrecht en handhavingsbeleid', in: F.C.M.A. Michiels \& E.R. Muller (red.), Handhaving. Bestuurlijk handhaven in Nederland, Deventer: Kluwer 2006, p. 8.

21 Black 2008, p. 18.

22 Black 2008, p. 24; 2010, p. 8 en 11. 
Volgens wetenschappelijke communis opinio zijn doelregelgeving en zorgplichten niet zo goed handhaafbaar als middelregelgeving. ${ }^{23}$ Doelregelgeving is minder goed controleerbaar (een doel is niet zo gemakkelijk visueel waarneembaar als een middel), overtreding ervan is minder goed bewijsbaar, en ze zou niet zo goed met sancties afdwingbaar zijn. De achilleshiel van zorgplichtbepalingen lijkt in de handhaving gelegen. Een handhaver kan meestal niet, zoals bij een middelvoorschrift, door het eenvoudig afvinken van te meten handelingen vaststellen dat aan de regels is voldaan. ${ }^{24}$ In vergelijking met middelregelgeving is de kwaliteit van de handhaving bij zorgplichten daarom lastiger te realiseren.

Het gezag van de handhaver bestaat uit ten minste drie componenten: ${ }^{25}$

1. zijn formele bevoegdheid om opdrachten te geven;

2. zijn expertise;

3. zijn feitelijke macht, bijvoorbeeld bij belonen en straffen.

Gezien de aard van zorgplichten zijn niet de formele bevoegdheid en de feitelijke macht van de handhaver zijn belangrijkste troeven, maar vooral zijn expertise. Omdat zorgplichten het moeten hebben van de deskundigheid bij de ondernemingen om zelf goede oplossingen te kiezen, dient de expertise van de handhaver daarbij aan te sluiten.

De strekking van zorgplichten is het bieden van meer ruimte aan de geadresseerde en dit uitgangspunt heeft zijn weerslag op de wijze van handhaven. De handhaving moet daarom niet zozeer gericht zijn op eenzijdig vaststellen, want dat zou geen recht doen aan die ruimte. Handhaving moet in eerste instantie het karakter hebben van een kwalitatief gesprek, dat wil zeggen een gesprek over de door de onderneming geformuleerde doelen, de wijze waarop die worden nagestreefd en de resultaten die worden vastgesteld. ${ }^{26}$ Deze aanpak komt overeen met het voortgezette discours van de communicatieve wetgeving.

\section{Een voorbeeld: vluchtmiddelen bij gevaarlijke stoffen in de binnenvaart}

\subsection{Het belang van casusonderzoek}

Een theoretisch kader voor inzicht in de werking van zorgplichten is ontleend aan de literatuur en aan de wetgevingspraktijk. Enkele belangrijke aspecten daarvan zijn in het voorafgaande belicht. De houdbaarheid van het kader is door mij getoetst aan de hand van een tweetal casestudies, vooral bestaande uit interviews met alle categorieën actoren en uit dossieranalyse. Het onderzoek had een

23 P. Jong, Handhaafbaar milieurecht. Bestuursrechtelijke handhaafbaarheid van milieurecht als normstellingsprobleem (diss. Amsterdam UvA), Amsterdam: Centrum voor Milieurecht (UvA) 1997, p. 122 e.v. en 160.

24 Dit hangt ook van het type doelregelgeving af. Waar de uitkomst van de doelnorm als een meetbare grootheid is gedefinieerd, zal de handhaving minder een probleem zijn dan bij een zorgplicht.

25 T. Blass, 'The Milgram Paradigm after 35 Years: Some Things We Now Know about Obedience to Authority', Journal of Applied Social Psychology 1999, nr. 29, p. 959 e.v.

26 Projectgroep zorgplichten primair onderwijs 2005, p. 46. In deze zelfde zin Mertens 2010. 
gemengd theorietoetsend en explorerend karakter, omdat het op basis van (diverse) bestaande theorieën heeft gezocht naar nieuwe antwoorden. ${ }^{27}$ Een andere reden voor casusonderzoek is dat op deze wijze de doelregelgeving in haar brede context, waaruit zij niet moet worden losgemaakt, kan worden geduid. ${ }^{28}$ Immers, discussies over de pro's en contra's van wetgevingsconcepten, zoals zorgplichten, worden dikwijls gevoerd met het oog op de wenselijkheid van dergelijke concepten in het algemeen. Een dergelijk concept kan daardoor geïsoleerd of geïdealiseerd voor het voetlicht komen. Daarmee wordt veronachtzaamd dat tal van factoren hun weerslag hebben op toepassing van de norm. In deze uit het leven gegrepen casusonderzoeken is getracht die bijkomende realiteiten waar mogelijk te betrekken.

\subsection{De vluchtmiddelennorm}

In een van de twee uitgevoerde deelonderzoeken staat de volgende zorgplichtbepaling centraal:

'Bij het laden of lossen van gevaarlijke stoffen in of uit binnenvaartschepen moet de opdrachtgever van het vervoer waarborgen dat zowel in de omgeving van het voor- als het achterschip geschikte middelen aanwezig zijn om het schip, ook in noodgevallen, te verlaten. ${ }^{29}$

Het betreft hier een internationaal voorschrift tot het toepassen van vluchtmiddelen. Normadressaten zijn de verladende terminals (hierna: verladers).

De vluchtmiddelennorm is tot stand gebracht door de Centrale Commissie voor de Rijnvaart (CCR) te Straatsburg, een internationale organisatie waarbij Nederland en een viertal buurlanden zijn aangesloten. De verplichting in haar huidige vorm is onder politieke druk, vooral van Nederlandse zijde, tot stand gebracht na een ernstig ongeval in 1999 op de Rijn te Dormagen (Duitsland). Daarbij raakte een schip bij het laden van benzine in brand, waarna nog een schip vlam vatte, met drie doden en een veelvoud aan gewonden als gevolg.

In de Nederlandse praktijk is de term vluchtmiddelen ingeperkt tot vluchtwegen, en zijn de noodgevallen beperkt tot brand. Deze nadere invulling of operationalisering is opgenomen in beleidsregels van de minister van Verkeer en Waterstaat (V\&W) en van de Inspectie Verkeer en Waterstaat. ${ }^{30}$ Omdat het gaat om interpreterende beleidsregels - want niet gebaseerd op een wettelijke bestuursbevoegdheid - zijn deze formeel niet bindend. Niettemin handhaaft de inspectie als ware sprake van verbindende voorschriften. De facto is dus sprake van een tweeledige norm: het internationale voorschrift en de nationale nadere invulling daarvan.

27 P. Verschuren \& H. Doorewaard, Het ontwerpen van een onderzoek, Utrecht: Lemma 2005, p. 171.

28 J.M. Hutjes \& J.A. van Buuren, De gevalsstudie. Strategie van kwalitatief onderzoek, Meppel: Boom 1996, p. 23.

29 Opgenomen in art. 1.4.2.3.1 van het Internationale reglement voor het vervoer van gevaarlijke stoffen over de binnenwateren (ADNR).

30 Benaming ten tijde van het onderzoek; thans: ministerie van Infrastructuur en Milieu respectievelijk Inspectie voor Transport en Leefomgeving. 
De inspectie ziet erop toe dat overal waar gevaarlijke vloeistoffen in de binnenvaart worden geladen of gelost goede brandwerende steigers worden aangelegd. Het bezwaar van de bedrijven, dat er ook andere gevaarlijke stoffen zijn dan brandbare, en andere calamiteiten dan brand, wordt niet gehoord. Daarbij speelt mee dat de CCR regels geeft zonder democratische controle. De afweging van de belangen binnen de CCR is niet transparant, noch is duidelijk welk motief aan de keuze voor de zorgplichtvorm ten grondslag heeft gelegen. De totstandbrenging van de norm in 1999 is dan ook niet ideaal geweest; datzelfde geldt ook voor de nadere invulling ervan door V\&W.

\subsection{Naleving algemeen}

Voor een succesvolle aspiratieve norm is het noodzakelijk dat de interpretatiegemeenschap de doelstelling ervan onderschrijft. ${ }^{31}$ Op papier maken de verladers uit de casus een goede kans om een (deel)interpretatiegemeenschap te vormen. ${ }^{32}$ De kennis en vaardigheden voor veilig laden en lossen zijn in het algemeen aanwezig bij verladers. Maar hoewel zij de veiligheidsdoelstelling van de norm onderschrijven, doen zij dat niet ten aanzien van de meer specifieke verplichtingen uit de nadere invulling door V\&W. Die operationalisering leidt ertoe dat de norm uiteindelijk weinig aspiratief en te veel instrumenteel is geworden. De verladers hebben het idee dat het voorschrift uitsluitend mag worden uitgevoerd op de wijze die V\&W heeft voorgeschreven. En verder is de norm niet tot stand gekomen noch uitgekristalliseerd als resultaat van een evenwichtig discours.

Een norm wordt het best nageleefd als de nalever het nut ervan inziet. Dit speelt vooral bij regels met een intrinsiek moreel karakter en een basis in het rechtsbewustzijn. ${ }^{33}$ Sociaaleconomische ordeningswetgeving ontbeert veelal een dergelijke diepgewortelde waarde. ${ }^{34}$ Bij de vluchtmiddelennorm zien we beide aspecten: $z i j$ draagt enerzijds een technisch karakter, hetgeen de naleving negatief zou kunnen beïnvloeden, ${ }^{35}$ maar heeft anderzijds een normatieve lading, waar het gaat om de veiligheid van personen. Een normatieve lading zal eerder dan een louter technische bepaling appelleren aan de professionaliteit van de geadresseerde, hetgeen een van de basisvereisten voor zorgplichtregelgeving is. Uit evaluatieonderzoek naar de Wet vervoer gevaarlijke stoffen blijkt dat de chemische industrie zich over het algemeen verantwoordelijk voelt voor de maatschappelijke gevolgen van het vervoer. ${ }^{36}$ In de gevaarlijke-stoffenbranche is het imago van veiligheid, reeds om economische redenen, van groot belang. Betrouwbaarheid draagt er immers toe

31 Van Klink 1998, p. 95.

32 De interpretatiegemeenschap die met de norm omgaat, is groter dan de verladers alleen en bevat bijvoorbeeld ook de vervoerders (schippers) en de handhavers.

33 W. Huisman, Tussen winst en moraal. Achtergronden van regelnaleving en regelovertreding door ondernemingen (diss. Amsterdam UvA), Den Haag: Boom Juridische uitgevers 2001, p. 304.

34 Y. Buruma, De strafrechtelijke handhaving van bestuurswetten, Politiestudies 10, Arnhem/Antwerpen: Gouda Quint 1993, p. 88.

35 W. Huisman \& A. Beukelman, Invloeden op regelnaleving door bedrijven, Den Haag: Boom Juridische uitgevers 2007, p. 29.

36 I. Helsloot, E.R. Muller, R. Pieterman \& W.J.M. Voermans (red.), Vervoer gevaarlijke stoffen in perspectief. Evaluatie van de Wet vervoer gevaarlijke stoffen 1996-2002, Den Haag: Boom Juridische uitgevers 2003, p. 80. 
bij dat op de lange termijn opbrengsten worden gerealiseerd uit de relaties. ${ }^{37}$ Kortom: de norm sluit aan bij het belang van de geadresseerde. Opmerkelijk is dat de schippers, tot wie de norm niet is gericht, maar die wel lijfelijk het eerste belang hebben bij de vluchtmiddelen, er minder om lijken te geven. Ze vinden het aanleggen van de beweegbare steigers vaak 'een hoop gedoe', bijvoorbeeld omdat die krassen kunnen veroorzaken aan hun schip. Het is dus maar goed dat de regelgever de verlader, en niet de schipper, als normadressaat heeft gekozen.

\subsection{Handhaving}

De belangrijkste factor die het functioneren van de vluchtmiddelennorm als zorgplichtbepaling in de weg blijkt te staan, zijn de genoemde nadere invullingen op de internationale norm door de minister en de inspecteur-generaal. Deze invullingen zijn, bezien naar hun inhoud, tamelijk specifiek (dirigistisch) en zowel de overheid als het bedrijfsleven beschouwt ze als verbindend. In feite is daardoor geen ruimte voor de ondernemer waarin diens deskundigheid zich vrijelijk heeft kunnen ontplooien. Het zorgplichtkarakter van de norm komt dan ook niet tot zijn recht. De gerichte inhoud van die nadere invullingen sluit niet aan bij de rijkdom aan mogelijkheden die er zijn om de norm uit te voeren. Soms zelfs staan die voorgeschreven invullingen naar het oordeel van de branche betere oplossingen in de weg. Ook neemt de inspectie een te dominante rol aan. De eigen beleidsvrijheid van de individuele handhavers is groot en mede daardoor komen bedrijven niet aan hun eigen oplossingen toe. Daarbij is het professionele discours, kenmerk van communicatieve wetgeving, onvoldoende uit de verf gekomen. De handhavingsstijl past niet bij doelregelgeving, want is meer gericht op sturing dan op discours. Dit alles leidt tot een geringe vrijwillige naleving in combinatie met een hoge handhavingsinspanning. De handelingsvrijheid van de geadresseerden is niet de eerste zorg van de overheid (ministerie, inspectie) gebleken. Het doel was om de veiligheid zo veel mogelijk met regelgeving te waarborgen en een daarbij passend stevig handhavingsregime toe te passen. De bedrijven van hun kant hebben ook niet de vrijheid genomen die hun toekwam, laat staan die in rechte opgeëist.

\subsection{Conclusie}

De norm van de CCR is in beginsel geschikt als doelvoorschrift: haar strekking is acceptabel, namelijk het bevorderen van de veiligheid van degenen die zich aan boord van het schip bevinden. De doelgroep van de norm bestaat uit professionele ondernemingen waarvan de deskundigheid zich veelal op het juiste niveau bevindt. Dat de inspectie over deskundige handhavers beschikt - een vereiste bij doelregelgeving - sluit hierbij goed aan. Echter, de nadere invullingen op de norm door minister en inspectie zijn bezwaarlijk. De doelstelling van de zorgplicht, te weten door het bedrijfsleven zelf op maat gesneden toepassingen, wordt niet bereikt.

37 J. van Erp, Informatie en communicatie in het handhavingsbeleid, Den Haag: Boom Juridische uitgevers 2007, p. 45. 


\section{Aanbevelingen voor de wetgever}

Het onderzoek heeft het inzicht in de werking van zorgplichten vergroot. Het heeft aanbevelingen opgeleverd voor de regelsteller om rekening mee te houden bij het formuleren van zorgplichtbepalingen. Deze aanbevelingen kunnen ook worden gebruikt als toetsingskader ex ante ter beantwoording van de vraag of een specifieke zorgplicht in de praktijk naar verwachting haar volle effect zal kunnen sorteren. Enkele aanbevelingen, samenhangend met het casusonderzoek, zijn de volgende.

\subsection{De norm}

De wetgever moet, anders dan in de casus is gebeurd, bij de inzet van doelregelgeving een goede afweging maken ten aanzien van motief, doelstelling of oogmerk. Het gaat daarbij om de in de literatuur genoemde zaken als: innovatiebevordering, stand van de techniek bijhouden of appelleren aan de beleidsvrijheid van de geadresseerde (en dus niet, zoals in de casus, aanvullende regels stellen met het oog op de handhaving). Als aan de gestelde norm geen passend motief ten grondslag ligt of het motief niet duidelijk is voor de normadressaat, kan de uitvoering ervan teleurstellen.

\subsection{De geadresseerde}

De regelgever en de toezichthouder ${ }^{38}$ zijn belangrijke actoren, maar de hoofdrol is weggelegd voor de normadressaat, wiens taak het is om aan de norm uitvoering te geven. Een uitgangspunt van doelregelgeving is dat de wetgever goed heeft nagedacht over de vraag hoe een bepaald voorschrift bij de normadressaat landt.

Een zorgplicht, zo leert het casusonderzoek, kan pas ruimte bieden aan de normadressaat als deze als zodanig wordt (h)erkend door alle betrokkenen. In de casus zijn de minister en de inspectie, de brancheorganisaties en de individuele normadressaten zich van dit karakter van de norm niet bewust geweest. Dit hangt samen met de ondoorzichtige wijze van totstandkoming van de norm. Aanbevolen wordt dan ook om te voorzien in een regelgevingsprocedure waarin de inbreng van de relevante belangen is geborgd - niet alleen die van brancheorganisaties, maar ook die van de daadwerkelijke normadressaten. Daarvoor valt te denken aan het organiseren van inspraakmomenten gedurende het regelgevingsproces, het houden van interviews, het inrichten van panels met respondenten uit 'het veld', het toepassen van internetconsultatie, het opzetten van werkgroepen of het organiseren van rondetafelgesprekken.

Uitgangspunt is dat de wetgever, als hij kiest voor een zorgplicht en niet voor middelvoorschriften, de handelingsvrijheid van de justitiabele borgt. Het is daarbij van belang dat de wetgever weloverwogen de normadressaat kiest, zoals ook in de casus is gebeurd. In het bijzonder moet de regelgeving aansluiten bij de belangen van de geadresseerden en passen bij hun professionaliteit. Het moet op voor-

38 De term toezichthouder wordt hier gebruikt als specifieke vorm van handhaver. Zoals in par. 7 betoogd, past immers het bestuurlijke toezicht, beter nog dan de strafrechtelijke handhaving, bij zorgplichtbepalingen. 
hand duidelijk zijn dat de doelgroep beschikt over de juiste mate van deskundigheid en professionaliteit en dat haar belangen parallel lopen met het belang dat de overheid met het stellen van de zorgplicht beoogt. Ook de belangen van derden moeten daarin mee worden betrokken; in de casus zagen we ook de diverse belangen, te weten van de verladers en van de schippers.

\subsection{Naleving}

In de casus speelt druk vanuit 'de politiek' een rol in het proces van normering, zowel bij de totstandbrenging van de norm zelf als bij de nadere invulling ervan door de overheid. Daardoor zijn de normadressaten niet in de gelegenheid gesteld om de norm in de loop der tijd te laten uitkristalliseren. Als er daarentegen een aspiratieve norm is waar geadresseerden 'iets mee hebben', een interpretatiegemeenschap en een discours om de norm te laten uitkristalliseren, dan heeft de wetgever de juiste weg ingeslagen. Uiteindelijk moet de focus ook gericht zijn op vrijwillige naleving.

\subsection{Handhaving}

De regelgeving moet de vrijwillige naleving ondersteunen door handhaafbaarheid. Een geëigende toezichthoudende dienst is daarvoor een eerste vereiste. Zo moet een toezichthouder, zeker omdat het een zorgplicht betreft, inhoudelijk deskundig zijn op het betrokken beleidsterrein. Professionaliteit van de toezichthouder betekent ook dat de individuele inspecteurs in staat en bereid zijn om de keuzen van de normadressaten op waarde te schatten en om daarover met hen het discours aan te gaan. Tussen de professionaliteit van de normadressaat en van de toezichthouder moet dan ook een match bestaan: het is belangrijk dat beiden dezelfde 'taal' spreken, als participanten van één interpretatiegemeenschap. Dan komt een passend evenwicht tot stand tussen de handhaving en de vrijwillige naleving.

\subsection{Beleidsregels als service}

Nadere voorschriften leiden, zoals we hebben gezien, tot starheid die zich niet verdraagt met het karakter van zorgplichtbepalingen. Maar er zijn normadressaten die duidelijkheid vooraf over de wijze van uitvoering op prijs stellen. Een uitweg uit dit dilemma is een nadere invulling van de norm door de overheid bij wijze van beleidsregels als service of suggererende regelgeving. Dat houdt in dat wie de norm volgens die beleidsregel van de minister of van de inspectie uitvoert, het zeker goed doet, maar dat andere wijzen van uitvoering ook zijn toegestaan. ${ }^{39}$ Dit is een zuiver voorbeeld van beleidsregels als vorm van zelfbinding door de overheid. Ondernemingen die niet de behoefte of de mogelijkheden hebben om optimaal gebruik te maken van de geboden handelingsvrijheid of die het interpreta-

39 J. Braithwaite, 'Rules and Principles; A Theory of Legal Certainty', Australian Journal of Legal Philosophy 2002, jrg. 27, p. 47-82 wijst op de mogelijkheid om niet-bindende regels toe te passen als achtervang voor de principles. Dit voorkomt dat geadresseerden zich onverwachts geconfronteerd zien met handhavingssancties (p. 30-31). 
tierisico ${ }^{40}$ van de norm niet willen dragen, kunnen dan eenvoudigweg aan deze beleidsregels gevolg geven. Maar bedrijven die zich meer inventiviteit kunnen veroorloven, mogen de norm op hun eigen wijze toepassen. ${ }^{41}$

Een voorbeeld in de arbowetgeving is de overheveling van middelvoorschriften naar de niet-bindende arbobeleidsregels. Deze bieden een referentiekader waaraan werkgevers praktische maatregelen kunnen ontlenen of eigen oplossingen kunnen afmeten. De Inspectie SZW (Arbeidsinspectie) hanteert ze als richtsnoer in de inspectiepraktijk. Een ander voorbeeld vinden we in het milieurecht. Daar kan aan doelvoorschriften, opgenomen in het Activiteitenbesluit milieubeheer, worden voldaan door specifieke voorschriften (erkende maatregelen) uit de Activiteitenregeling milieubeheer toe te passen. Niettemin mag de geadresseerde ervoor kiezen om aan een doelvoorschrift een eigen invulling te geven.

In de casestudie blijkt bij het bedrijfsleven voor een dergelijke aanpak draagvlak te zijn. Een vertegenwoordiger van het bezochte havenbedrijf merkte op:

'Het zou fijn zijn als je kon zeggen: doelregelgeving, oké. Maar voor diegene die het niet helemaal tot de bodem kunnen uitzoeken hebben we een aantal best practices. Als je het volgens die best practice doet, dan zit je goed. Dan hoef je niet ingewikkeld te doen. En als een of ander groot industrieel bedrijf zegt: ik weet het veel beter, ik laat het echt helemaal uitzoeken en kies mijn eigen oplossing - dat zou in mijn ogen de ideale situatie zijn.'

Ook andere vormen van aanpak zijn denkbaar, zoals metatoezicht. Het betrokken bedrijf overlegt dan bijvoorbeeld de verklaring van een gecertificeerde deskundige dat aan de voorschriften is voldaan. De inspectie houdt daarmee toezicht op het proces in plaats van op de prestatie. En een meer inhoudelijk toetscriterium of is voldaan aan de norm zou kunnen zijn: is een transparante methode om risico in te schatten toegepast volgens de stand van de wetenschap? Voorts is managementtoezicht een optie. Hierbij stelt de toezichthouder vast of op bedrijfsniveau voldoende waarborgen zijn getroffen voor een goede naleving van de norm. ${ }^{42} \mathrm{Wel}$ lijkt mij een nadeel van deze toezichtvormen de grotere afstand van de toezichthouder tot de werkvloer en daarmee de verschraling van de dialoog, gericht op de inhoud van het toezichtobject. Zeker bij veiligheidsregelgeving moeten dergelijke concepten met de nodige voorzichtigheid worden toegepast, opdat de overheid haar betrokkenheid erbij niet verliest.

40 Dit is het risico met het oog op bijvoorbeeld de handhaving, als het doelvoorschrift verkeerd zou worden toegepast; Black 2008, p. 18.

41 Het 'doel', zoals opgenomen in het doelvoorschrift, is dus uitgewerkt in een beleidsregel; die twee (namelijk het wettelijke doelvoorschrift en de beleidsregel) zijn daarmee naast elkaar geldig.

42 Black 2008, p. 22; 2010, p. 8. 